\title{
COMBINED LEARNING DURING CONFINEMENT: UNDERGRADUATE STUDENTS OPINIONS
}

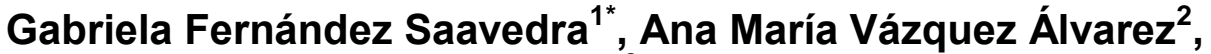 \\ Beatriz Georgina Montemayor Flores ${ }^{3}$ and José Antonio Rojas Ramírez ${ }^{4}$ \\ ${ }^{1}$ Pharmacology, Medicine School, Universidad Nacional Autónoma de México, México \\ saavegaby@gmail.com \\ ${ }^{2}$ Phisiology, Medicine School, Universidad Nacional Autónoma de México, México. \\ anavazalv@yahoo.com.mx, \\ ${ }^{3}$ Anatomy, Medicine School, Universidad Nacional Autónoma de México, México \\ betyg@unam.mx, \\ ${ }^{4}$ Pharmacology Medicine School, Universidad Nacional Autónoma de México, México \\ rojasrja@yahoo.com \\ ${ }^{*}$ Corresponding Author
}

\begin{abstract}
At the end of the Pharmacology course, a feedback exercise was carried out, in this activity the students pointed out the activities that were useful to them during the school year, as well as suggestions, observations and disagreements; this accumulation of information was analyzed and taken into account for the planning of future courses. The feedback was done when there were no more pending school activities and student participation was voluntary. The teachers asked the students to submit their opinions in writing, and their consent was also sought for publication. Given the pandemic we are experiencing, a necessary element in planning for the next course is the combination of elements from the classroom environment with tools from the virtual environment, also known as B-learning. During the pandemic, the change from classroom to virtual learning was sudden and unplanned, but it was the only alternative in the face of the impending health crisis. Taking into account students' suggestions and teachers' experiences during the first months of confinement, it is prudent to train teachers in the use of technological tools needed for teaching. In this work, both the students' suggestions and the virtualized versions of them are presented, as well as the adjustments from the teacher's point of view.
\end{abstract}

Keywords: B-learning, Blended learning, pandemic, undergraduate studies

\section{INTRODUCTION}

The teaching of Pharmacology in the Faculty of Chemistry is in presence modality, the subject contemplates both theoretical and practical elements; however, this year the presential school activities stopped suddenly before the imminent arrival of the COVID-19, the suspension of the activities and the confinement was the only alternative to stop the dispersion of the virus; however, the National Autonomous University of Mexico reorganized its human and digital resources to continue with its essential activities, (UNAM, 2020; UNAM, B., 2020). The professors continued and concluded the activities that they had been carrying out, since they did not have access to the campus they had to implement technologically mediated communication, at first with the cell phone, then with the use of social networks, the creation of rooms for groups, email, readings in PDF 
format, summaries and reports that the students elaborated and sent to their teachers in Word format, shared activities and collaborations with their peers, protocols sent or shared from Google Docs, using the institutional cloud among others. At the end of the courses, the general balance was good, because even under adverse circumstances the objective of the official program of the subject was achieved. With this experience, the teachers proved the usefulness of technological tools, they also revaluated the benefits of the Internet, and recognized that without it and its tools this would not have been possible, because the official provision was to stay at home, not to make meetings, maintaining a minimum distance between individuals of 1.5 meters. In order to plan the next course, a review was initiated, taking into account the information gathered from the students and the verbal comments of some teachers.

In this work, the tools and elements suggested by the students who studied Pharmacology are presented, also the virtual alternatives of the tools with which they continued working are included and finally the observations and reflections of the authors are added. The combined learning or B-learning (Ibáñez, et al., 2018), was very useful during this contingency.

\section{METHODOLOGY}

Pharmacology students were invited to participate in a feedback exercise. The students collaborated voluntarily and were asked for their consent to publish the information collected. Although the groups are approximately 30 students, only 15 students submitted the written request, the identity of the participants is anonymous. This activity took place after handing in grades and attending to clarifications and disagreements. In the feedback activity, we asked what elements the Pharmacology class should contain to favor learning and if there was any element or attitude that was unpleasant or that prevented group communication and learning. Additionally, the technological tools used by the students were collected and others were sought that could be useful during the confinement.

\section{RESULTS}

In Table 1. Student suggestions and virtual alternative, we included the activities traditionally performed by students, their virtual equivalent and the observations or considerations for their use. The classroom teacher should make modifications in his or her strategy, rather than deciding how many and what tasks to assign, he or she should be trained in Educational Communication, which should be persuasive, argumentative, assertive, etc., (Córica, 2012). It is important that the assigned tasks are reviewed, and feedback is planned to correct doubts and ambiguities. In the case of summaries or written documents such as essays and practice report it is important to prepare a rubric and explain them to the students, this will facilitate the elaboration of the writing and improve its grade. It is important to monitor the delivery of student work. When a student falls behind, the teacher should discuss the reasons with him or her and provide support as much as possible. A frequent comment among teachers was that the workload is very high when the course has to be virtualized, this perception was held by the vast majority of teachers who are mostly digital migrants.

As can be seen in Table 1. Suggestions from the students and considerations for their virtualization, the participants indicated that the readings of book chapters located in the library had been very helpful, as well as some notes made by the professor and articles, all of which helped them to understand and perform the activities better. Therefore, since there are no face-to-face classes, virtual alternatives can be used (UNAM, B., 2020; Google-Books, 2020), which implies that the professor must make sure that the documents are complete or send them in PDF format. On the other hand, the classes given using master conferences that face-to-face teachers are used to can be replaced with videoconferences and videos. The application of prepractice questionnaires or exams can be replaced by online exams.

Finally, the crosswords that help to review concepts, definitions and principles, can be replaced by virtual versions that are already available (Educima.com, 2020; Educaplay, 2020). In Table 2. Virtual versions to continue with the teaching, some alternatives are shown for each activity suggested by the students.

As it can be seen, there are many alternatives that can be used when virtualizing each classroom activity, but it should be stressed that training is essential to avoid incidents that some of the teachers commented on:

a) Inappropriate behaviors such as insults and bullying when using a social network that lacks security.

b) Sharing the link of a video conference by social network, which caused outsiders to enter and interrupt the session. 


\begin{tabular}{|c|c|c|c|}
\hline \multicolumn{4}{|c|}{ Table 1. Student suggestions and considerations for virtualization } \\
\hline Activity & $\begin{array}{l}\text { Traditional } \\
\text { Format }\end{array}$ & Virtual Alternative & Considerations \\
\hline \multirow[t]{2}{*}{ Reading } & Book Chapters & E-Books & $\begin{array}{c}\text { Search in advance, check availability } \\
\text { and share the link }\end{array}$ \\
\hline & Artíicles & $\begin{array}{c}\text { Digital version. } \\
\text { Downloaded or online }\end{array}$ & $\begin{array}{c}\text { Copying the link and share it or } \\
\text { download the PDF document to share }\end{array}$ \\
\hline $\begin{array}{l}\text { Identification of } \\
\text { special } \\
\text { elements }\end{array}$ & Written quiz & Digital Quizzes & $\begin{array}{l}\text { They can send the link or send the } \\
\text { printed version. }\end{array}$ \\
\hline $\begin{array}{l}\text { Test previous } \\
\text { to the practice. }\end{array}$ & Written test & Digital Quizzes & $\begin{array}{l}\text { They can send the link or send the } \\
\text { printed version. }\end{array}$ \\
\hline Crosswords & Written & Virtual crosswords & $\begin{array}{l}\text { They can send the link or send the } \\
\text { printed version. }\end{array}$ \\
\hline Summaries & Written & $\begin{array}{c}\text { Elaborated in Word or } \\
\text { Google Docs }\end{array}$ & $\begin{array}{c}\text { They can send the mail or Google } \\
\text { Drive link. }\end{array}$ \\
\hline $\begin{array}{l}\text { Reading } \\
\text { Debates }\end{array}$ & In person & Videoconference & It can be in Zoom or Google Rooms \\
\hline Team repports & $\begin{array}{l}\text { In person or } \\
\text { written }\end{array}$ & $\begin{array}{l}\text { Collaboration in writing the } \\
\text { report in Google Docs, } \\
\text { communication by video } \\
\text { call }\end{array}$ & $\begin{array}{c}\text { Google account required and previous } \\
\text { planning as well. }\end{array}$ \\
\hline
\end{tabular}

Table 2. Virtual versions to continue with the teaching

\begin{tabular}{|l|l|l|}
\hline \multicolumn{1}{|c|}{ Activity } & \multicolumn{1}{|c|}{ Virtual Alternative } & \multicolumn{2}{|c|}{ Suggestion } \\
\hline \multirow{2}{*}{ Reading } & Digital Books (E-Books) & $\begin{array}{l}\text { Dirección General de Bibliotecas } \\
\text { UNAM* (UNAM, B., 2020) } \\
\text { Google books }\end{array}$ \\
\cline { 2 - 3 } & $\begin{array}{l}\text { Digital version to read online or } \\
\text { download the document. }\end{array}$ & $\begin{array}{l}\text { Dirección General de Bibliotecas } \\
\text { UNAM } \\
\text { (UNAM, B., 2020) }\end{array}$ \\
\hline $\begin{array}{l}\text { Essential elements } \\
\text { research }\end{array}$ & Digital Quizzes & Google Questionnaires \\
\hline $\begin{array}{l}\text { Test previous to the } \\
\text { practice or session. }\end{array}$ & Digital Quizzes & Google Questionnaires \\
\hline Crosswords & Virtual Crosswords & $\begin{array}{l}\text { Educima } \\
\text { Educaplay }\end{array}$ \\
\hline Summaries & Created in Word or Google Docs & Google Docs \\
\hline Reading Debates & Videoconference & Zoom, Meet, Whats App \\
\hline Team Reports & $\begin{array}{l}\text { Collaboration in writing the report in } \\
\text { Google Docs, communication by } \\
\text { video call. }\end{array}$ & Google Docs \\
\hline${ }^{*}$ requires a password to enter, asks for students information. \\
\hline \multicolumn{2}{|c|}{ Table 2. Virtual versions to continue with the teaching } \\
\hline
\end{tabular}

c) Requesting reports without a rubric, which caused disagreement with the score obtained.

d) Making video calls without checking in advance the operation of the microphone and the sound, without taking care of the environment and the presence of distractors.

e) Updated anti-virus to avoid damage to files and computers,

f) Download applications from social networks that are unsafe, instead of looking for the official site and read carefully the rules of use.

All these incidents can be avoided through proper training, taking into account that there are always new elements in which one might not have a mastery of the tool to be used, it will be wise to request support from 
technical staff in this area or seek another alternative. Another problem that has not yet been quantified is the percentage of the student population that faces financial crisis because their tutors lost their sources of income during confinement.

One aspect that is indispensable is the support of specialized teaching staff (psycho-pedagogues, didactics specialists, etc.) because blended learning is not a copy of the classroom environment, it requires careful planning, congruence between objectives, procedures, results and evaluation. The teacher must be in continuous training, in aspects such as communication, the design of classroom activities, etc., some authors who study teaching in virtual environments point out how important it is to prepare in teaching, cognitive and social aspects (Cabrero, \& Ortega, 2011).

\section{CONCLUSIONS}

The planning of the Pharmacology sessions should meet the objectives of the program; by taking into account the students' opinions this activity is enriched, benefiting both the students' learning and the teacher's teaching. From each activity we looked for its virtual equivalent, since it was proved the benefit of these tools, which would have gone unnoticed if it were not for the preventive and compulsory confinement in the face of the health crisis by the Covid-19. The benefits of combining presential and virtual elements have allowed continuing with the essential activities of the Chemistry College, so it is prudent to train teachers in B-learning.

\section{REFERENCE LIST}

Cabrero, B. G., \& Ortega, V. J. P. (2011). Evaluar la docencia en línea: retos y complejidades. RIED. Revista iberoamericana de educación a distancia, 14(2), 63-76.

Córica, M. J. L. (2012). Comunicación y nuevas tecnologías: su incidencia en las organizaciones educativas.

Concepto de comunicación educativa"[Documento en PDF]. Recuperado de http://www. uaeh. Edu $\mathrm{mx} /$ docencia/VI_Lectura/maestria/documentos/LECT46. pdf.

Educima.com. 2020. Inicio. [online] Disponible en: https://www.educima.com/crosswordgenerator.php <https:

[Accessed 01 August 2020].

Educaplay. 2020. Inicio. [online] Disponible en: https://es.educaplay.com/tipos-deactividades/crucigramas.html [Consultado el 02 agosto 2020].

Google-Books. 2020. Inicio. [online] Disponible en: <https: https://books.google.com/bkshp?hl=es-419> [Consultado el 2 de agosto 2020].

Ibáñez, J. S., de Benito Crosetti, B., Garcías, A. P., \& Cervera, M. G. (2018). Blended learning, más allá de la clase presencial. Revista Iberoamericana de Educación a Distancia, 21(1), 195-213.

UNAM, B., 2020. Biblioteca Digital UNAM - Inicio. [online] Bidi.unam.mx. Disponible en: $<$ https://bidi.unam.mx/> [Consultado el 02 agosto 2020].

UNAM ha llevado a cabo 91 acciones contra la pandemia de COVID-19. (2020, 05 de agosto). Disponible en: https://alcanzandoelconocimiento.com/unam-ha-llevado-a-cabo-91-acciones-contra-la-pandemiade-covid-19/ 